\title{
Perceived Stress and Coping Mechanisms among Teachers in Three Special Schools in the Northern Parts of Ghana
}

\author{
Alimatu Cecilia Issakah", ${ }^{1, *}$ Isaac Nyame ${ }^{1}$, Fatima Iddrisu Abu ${ }^{2}$ \\ ${ }^{1}$ Faculty of Education, University for Development Studies, Ghana \\ ${ }^{2}$ Department of Languages and Liberal Studies, Tamale Technical University, Ghana
}

Received October 20, 2021; Revised November 22, 2021; Accepted December 10, 2021

\section{Cite This Paper in the following Citation Styles}

(a): [1] Alimatu Cecilia Issakah, Isaac Nyame, Fatima Iddrisu Abu , "Perceived Stress and Coping Mechanisms among Teachers in Three Special Schools in the Northern Parts of Ghana," Universal Journal of Psychology, Vol. 9, No. 2, pp. 9 - 22, 2021. DOI: 10.13189/ujp.2021.090201.

(b): Alimatu Cecilia Issakah, Isaac Nyame, Fatima Iddrisu Abu (2021). Perceived Stress and Coping Mechanisms among Teachers in Three Special Schools in the Northern Parts of Ghana. Universal Journal of Psychology, 9(2), 9 - 22. DOI: 10.13189/ujp.2021.090201.

Copyright $\odot 2021$ by authors, all rights reserved. Authors agree that this article remains permanently open access under the terms of the Creative Commons Attribution License 4.0 International License

\begin{abstract}
The aim of this study was to find out perceived stress and coping mechanisms among teachers in special schools in the northern part of Ghana. This study was an explorative study with quantitative survey as its main design. Teachers in three special schools formed the population of the study. The proportionate simple random sampling was used to select 60 teachers for the study. A self-constructed questionnaire was the main instrument for the study. Data were collected personally by the researchers. The data obtained were analysed in SPSS using frequency distribution tables and percentages as well as means and standard deviations. Also, independent t-test, one-way analysis of variance, and Pearson correlation coefficient were run to determine the relationship between some demographic factors and the variables investigated. It was found that several factors cause stress among special educators, such as low remuneration and lack of pupils' progress. The effects of stress included cardiovascular diseases, headaches, depression, and anxiety. The teachers' responses showed that leaving the stressful event, seeking administrative support, and a sense of efficacy were some coping strategies adopted. It was concluded that several factors cause stress among special educators with physical, psychological and behavioural effects, hence there is a need for effective coping strategies to make them stay safe and healthy. It was recommended that social support systems should be made an integral part of the teachers' job to make them cope adaptively to stressful situations.
\end{abstract}

Keywords Stress, Coping Mechanism, Teachers, Special Schools

\section{Introduction}

Stress is an inescapable reality in today's world and affects individuals regardless of one's status [35]. Stress is a necessary part of our lives and may have both beneficial and detrimental effects. In recent times, work is not only considered as the source of infinite fulfilment and satisfaction, it has also become a source of stress and discontentment among many workers [43]. Work-related stress is a major public health issue around the world, affecting both the health and well-being of employees and the productivity of organizations. Occupational stress has attracted lots of attention in research in many organizations. It is evident that teacher stress and burnout have become an area of interest among researchers and practitioners [32].

Clipa [28] conceived that teacher stress may be more detrimental compared to stress levels experienced in other jobs. Stress associated with teaching may consist in the teacher experiencing some negative emotions including tension, anxiety and depression which often result from some aspect of his job [46]. With increasing demands for teacher accountability, the teacher's workload has increased and this has left many of them with emotional 
fatigue. One's ability to successfully manage stress that results from daily learning, behavioral and emotional needs of students with disabilities are very critical [50].

Teaching was ranked first in occupational stress, according to a survey assessing the stress levels of various jobs [43]. Antoniou [6] found that among all other professions, teachers experience higher levels of stress than other occupations. According to Kaur [43], the work of a teacher is difficult since a teacher must spend a great deal of energy on his or her daily classroom activities as well as personal and family commitments. International research has confirmed that teaching is the most stressful profession in today's society [8], [14], [36].

Though teaching in general has been reported as stressful, it appears teaching in special schools may be much more stressful compared to teaching in the general schools [61]. Cancio, [23] reported from their study that teachers who work in special schools experience work-related stress which affects their work output. It has been reported that the special educator's job is usually more difficult, demanding, and stressful than that of general educators [11]. Several studies have reported that teachers who work in special schools encounter several challenges that lead to burnout. Among these are work overload, role ambiguity, poor administrative support, unlimited paperwork, feeling of isolation and loneliness due to reduced contact with colleagues [2], [24], [37], [40], [42], [51], [56].

Every year, a greater number of teachers leave special schools for the mainstream schools and others completely leave teaching to join other professions. This among factors suggests that job-related stress may be a major cause of turnout intentions and employee attrition in special schools. Cancio [23] argued that special schools face greater teacher shortages due to burnout associated with the teachers' work. Despite extensive research on stress and coping among teachers in general, Cancio [23] argues that little evidence exists on stress perception and ways special educators cope with and manage their stress. Previous research on stress among teachers in special schools has revealed a slew of potentially exacerbating factors.

Special education teachers usually experience common occupational stressors such as work overload, particularly in curriculum development, behaviour management, instructional adaptations, planning and delivery of lessons, engagement and administration [8], [14], [18]. Other stressors that have been reported among special needs educators include role conflict, and role ambiguity [38], lack of instructional support, inadequate supply of materials, strain with colleagues and administrators or parents [48], and limited professional training [4].

Similarly, some studies have reported poor school climate, excessive workload, poor collegial support [26], lack of professional recognition, excessive administrative work, time constraints, and excessive paperwork [20]; [51]; large class size, and isolation, as contributors of special education stress and burnout [51]. Adeniyi [1] found lack of pupils' progress, lack of teacher aides, and increased enrolment as contributors to stress and burnout among special needs education teachers. Again, Ghania [39] in their study of stress among teachers in special education in Malaysia found pupils' problem behaviours, time constraints, limited supply of resources, poor interpersonal relationships and low recognition as the major stress factors among teachers in special schools. These sources of stress among special educators may have various effects on them.

Crider [31] argued that the cost of stress in terms of human suffering, social and occupational impairment, and illness are enormous. There is increasing research evidence for a link between stress and illness [47], [53], [54]. According to Brown [17], long-term stress affects teachers' physical and mental health, producing physiological, psychological, and attributional responses. They argued that physiological responses include elevated blood pressure and headaches, psychological responses include depression and anxiety, and attributional responses are evident in teachers' reports of feelings of inferiority, resignation and helplessness [51].

Job stressors may also have dire consequences, including physical ailment, voluntary retirement [27], heart attacks, poor relationships with colleagues, anxiety, general feeling of inadequacy [52], lingering fatigue, depression and burn-out symptoms [12]. Effects of teacher stress may have various dimensions including physical (high blood pressure, headaches, migraine), psychological (depression, anxiety, suicidal ideation, low self-esteem), behavioural (absenteeism, fatigue, resignation), and social (interpersonal conflicts, hostility with pupils and colleague teachers) among others. This means that teacher stress can have serious negative impacts not only on his health but also his relation with others and attitude towards work which combine to affect his overall output with consequential effects on the students' performance.

Brown [17] indicated that there may be two major classifications of the effects of stress on teachers which are environmental and emotional. The environmental or external ones are linked to the teacher's work as well as the teaching process. On the other hand, the emotional or internal effects concern inner feelings resulting in anger, anxiety, low motivation and distress experienced by teachers in their quest to handle job stress. The two influences are extremely interlinked [57] and affect how teachers perform their jobs.

The physical, psychological, social and behavioural impacts of stress require strategies that are effective to make teachers stay healthy and do their work effectively since their coping techniques affect their health, quality of life, and eventually their commitment towards teaching [23]. Betoret [12] argued that teachers who are exposed to coping resources may less likely experience burnout relative to those with limited coping strategies. Thus, coping mechanisms reduce any effect of stress by altering one's emotional state, reducing or completely eliminating the cause of stress [44]. It involves modifying 
psychological and behavioural strategies to overcome specific strains that exceed the ability and personal coping skills [45]. With effective coping strategies, teachers may have the capacity to solve problems, access social support, and develop capacities for teaching in order to enhance their effectiveness in their work [49].

In addition to adaptive coping techniques such as regular exercises and meditation, evidence exists to demonstrate how support networks may help educators to cope productively with stress [9], [25]. It is also evident that sharing useful teaching skills and behaviour management techniques may be critical ways of coping with stress among educators. It has been suggested [41] that colleagues can often render invaluable support, especially among special educators as they navigate their daily responsibilities. Direct and indirect support from lead teachers and colleagues may lead to increased commitment, especially for new special educators. Special educators who see themselves as members of a professional community are more likely to have access to important resources [41]. Likewise, professional organizations also provide a plethora of opportunities for professional development, such as conference workshops, publications, networking, webinars, and blogs.

Professional development in which teachers learn new techniques for imparting academic knowledge as well as ways to effectively communicate that knowledge through behavior management has been identified as an important contributor to teacher resilience and retention [3], [9]. Membership in a professional organization can thus provide a vital link to the support needed to help a special educator deal with stress, and promote his or her retention in the field.

According to Billingsley [13] and Brownell [19], special education teachers have a higher attrition rate than general education teachers. Similarly, Williams [60] has observed a similar pattern of attrition among South African special education teachers. However, such findings have not been reported in research literature, especially in the Northern part of Ghana. Meanwhile, poor societal attitudes to disability are still widespread and therefore teacher stress and attrition can be envisaged in this region. The teachers' perceived stress and ways of coping therefore require investigation to inform policy and practice. This study therefore sought to investigate perceived stress and coping mechanisms among special educators in the Northern parts of Ghana.

\section{Purpose of the Study}

The purpose of this research was to find out factors associated with stress among special education teachers, effect of stress, and the strategies used by these teachers to cope with their stress.

\section{Research Questions}

1. What are the sources of stress among special education teachers?
2. What are the effects of stress on special education teachers?

3. What strategies do teachers in special schools use to cope with their stress?

\section{Research Methodology}

The method section details the systematic process of choosing the population, selecting the sample, collection of data using a research instrument and data analysis. The research design was the comparative survey design, which is the design of choice for assessing knowledge, beliefs and attitudes. This design was especially suitable considering that teachers had to report on their experience and impressions of the stress situation in which they operated and how they reacted to the stressful situation to make it less stressful.

The population of the study involved all teachers in three special schools (Savelugu School for the Deaf; Yumba School for Children with Intellectual Disabilities; and Wa Methodist School for the Blind) from the Northern part of Ghana. The schools were selected from three regions in the Northern part of Ghana with one school chosen from each region. In Ghana, the special school system is still categorized into three disability categories: schools for the blind, schools for the deaf, and schools for the intellectually disabled.

The schools were selected from three clusters based on three regions; Northern, Upper East and Upper West regions of the country. Since teachers in the schools were not large, the researchers employed the census approach in which all the population participated in the study. However, during the data collection some teachers were not available, hence they could not participate in the study. It was however evident that the number that was obtained showed a proportionate representation of teachers of the three schools, hence each school was fairly represented [55]. Fifteen out of 17 teachers from the Yumba school for the intellectually disabled participated in this study. Also, 20 teachers out of 23 teachers from the Wa Methodist School for the Blind participated in the study, and 25 out of 27 teachers from the Savelugu School for the Deaf participated in the study.

A Questionnaire was used to collect data. The Questionnaire comprised three sections apart from the demographic items with each section soliciting information about the sources of stress, effects of stress and coping strategies respectively. The items on the questionnaire were rated on a 5-point Likert scale (Never, Rarely, Sometimes, Often, and Always). The questionnaire was subjected to expert approval to ensure face and content validity. The questionnaire was also piloted with 5 teachers from each school to determine its appropriateness for the main data collection. The internal consistency was estimated using Cronbach alpha, which is conveniently used to estimate the internal consistency of composite items. The Cronbach alpha for the instrument was 0.78 . 
Participants were given informed consent form to complete before the study. This was to guarantee their volunteerism. In the informed consent, the teachers were assured of confidentiality and anonymity. The first part of the questionnaire solicited information about the sources of stress and had 16 items while the second and the third sections soliciting information about the effects of stress and coping strategies had 18 and 14 items respectively.

Sixty responses to the questionnaires were obtained and the data obtained from the questionnaires were numbered serially to make sure each of them was intact and appropriately identified for analysis. The items on the questionnaire were coded into SPSS (v.25). The data were then entered for analysis. Frequency distribution tables and percentages were used. The means and standard deviations were also presented. Independent t-test, one-way analysis of variance, and Pearson moment correlation coefficient were run to obtain the relationship between and among some demographic variables and the main variables investigated in this study.

\section{Results}

The data presented here were obtained from the field through the administration of the questionnaires to teachers in the three special schools. There were 40 (66.7\%) males and 20 (33.3\%) female teachers in three special schools who participated in the study. Only $3(5 \%)$ of the participants had secondary school certificates, 17 (28.3\%) had Certificate A, 20 (33.3\%) were diploma certificate holders, 17 (28.3\%) had first degree and the rest 3 (5\%) had master's degree. Sixteen (26.7\%) of the teachers taught in early grade from kindergarten to grade 3, 18 (30\%) taught in the primary school (grade 4 to grade 6), and the rest 26 (43.3\%) taught in Junior High School. The data revealed that $14(23.3 \%)$ had taught in the special school within 5 years and 11 to 15 years respectively, 29 (48.3\%) had taught between 6 to 10 years, only 3 (5\%) had taught in the special school for more than 15 years. Forty (66.7\%) of the participants were married while the rest 20 (33.3\%) were single. Only 14 (23.3\%) of the teachers were Christians, 25 (41.7\%) were Muslims, 9 (15\%) claimed they belong to the African Traditional Religion, and the rest 12 (20\%) said they belonged to other religions.

Fourteen (23.3\%) of the teachers they taught between 5 to 10 hours a week, 25 (41.7\%) taught between 11 to 15 hours, 6 (10\%) taught within 16 to 20 hours and the rest 15 (25\%) taught for more than 20 hours a week. Similarly, on preparation hours, $10(16.7 \%)$ claimed they spent 1 to 3 hours preparing, 27 (45\%) said they spend 4 to 6 hours in their preparation, $10(16.7 \%)$ said they spend 7 to 9 hours preparing for their lessons in a week while 13 (21.7\%) claimed they spend more than 9 hours in their preparation.

The data obtained from the main instruments are presented in Tables 1 to 3 . The items were rated on a 5-point Likert scale of never, rarely, sometimes, often and always. However, for easy presentation of the data, responses to Never and Rarely were combined under Rarely and similarly responses Often and Always were Combined as Often as depicted in the Tables 1, 2 and 3. Frequencies and percentages as well as their corresponding means and standard deviations are presented in the Tables 1,2 and 3.

Table 1. Sources of Stress among Special Education Teachers

\begin{tabular}{|c|c|c|c|c|c|c|}
\hline S/No. & Sources of stress & Rarely & Sometimes & Often & Mean & Std. Dev. \\
\hline 1. & Increased teaching hours per week & $40(66.6 \%)$ & $8(13.3 \%)$ & $12(20 \%)$ & 2.3 & 1.4 \\
\hline 2. & Increased pupil enrolment & $11(18.3 \%)$ & $4(6.7 \%)$ & $45(75 \%)$ & 3.8 & 1.2 \\
\hline 3. & Lack of pupils’ progress & $17(28.3 \%)$ & $13(21.7 \%)$ & $30(50 \%)$ & 3.2 & 1.2 \\
\hline 4. & Special attention to individual pupils & $21(35 \%)$ & $9(15 \%)$ & $30(50 \%)$ & 3.2 & 1.3 \\
\hline 5. & Pupils’ misbehaviour & $20(33.3 \%)$ & $11(18.3 \%)$ & $29(48.3 \%)$ & 3.2 & 1.2 \\
\hline 6. & Lack of support staff & $41(68.3 \%)$ & $10(16.7 \%)$ & $9(15 \%)$ & 2.4 & 1.0 \\
\hline 7. & Lack of support from head teacher/administrator & $21(35 \%)$ & $9(15 \%)$ & $30(50 \%)$ & 3.4 & 1.4 \\
\hline 8. & Poor relationship with colleagues and head teacher & $39(64 \%)$ & $10(16.7 \%)$ & $11(18.3 \%)$ & 2.4 & 1.1 \\
\hline 9. & Inadequate teaching learning materials and resources & $24(40 \%)$ & $12(20 \%)$ & $28(46.7 \%)$ & 3.1 & 1.2 \\
\hline 10. & Lack of government support & $27(45 \%)$ & $10(16.7 \%)$ & $23(38.3 \%)$ & 2.9 & 1.3 \\
\hline 11. & Lack of parental involvement & $18(30 \%)$ & $7(11.7 \%)$ & $35(58.3 \%)$ & 3.4 & 1.3 \\
\hline 12. & Desire to change job & $20(33.3 \%)$ & $7(11.7 \%)$ & $33(55 \%)$ & 3.2 & 1.2 \\
\hline 13. & Lack of motivation & $39(65 \%)$ & $9(15 \%)$ & $12(20 \%)$ & 2.4 & 1.2 \\
\hline 14. & Low income or salary & $13(21.7 \%)$ & $5(8.3 \%)$ & $42(70 \%)$ & 3.7 & 1.3 \\
\hline 15. & Limited professional training and development & $9(15 \%)$ & $5(8.3 \%)$ & 46 (76.7\%) & 3.9 & 1.2 \\
\hline 16. & $\begin{array}{l}\text { Stressful professional interactions with colleagues, } \\
\text { administrators or parents }\end{array}$ & 12 (20\%) & 20 (33.3\%) & $28(46.7 \%)$ & 3.2 & 0.9 \\
\hline
\end{tabular}

AVERAGE MEAN = 3.10625; AVERAGE SD = 1.2125 
Table 2. Effects of Stress on Special Education Teachers

\begin{tabular}{llccccc}
\hline S/no. & Effects of stress & Rarely & Sometimes & Often & Mean & Std. Dev. \\
\hline 1. & Increased Blood pressure & $28(46.7 \%)$ & $16(26.7 \%)$ & $16(26.7 \%)$ & 2.8 & 1.1 \\
2. & Cardiovascular disease & $23(38.3 \%)$ & $14(23.3 \%)$ & $23(38.3 \%)$ & 3.1 & 1.2 \\
3. & Headaches & $12(20 \%)$ & $11(18.3 \%)$ & $37(61.7 \%)$ & 3.5 & 1.2 \\
4. & Depression & $16(26.6 \%)$ & $5(8.3 \%)$ & $39(64 \%)$ & 3.4 & 1.3 \\
5. & Anxiety & $15(25 \%)$ & $10(16.7 \%)$ & $35(58.3 \%)$ & 3.4 & 1.2 \\
6. & Feeling of inferiority & $9(15 \%)$ & $7(11.7 \%)$ & $44(73.4 \%)$ & 3.7 & 0.9 \\
7. & Suicidal thought & $15(25 \%)$ & $4(6.7 \%)$ & $41(68.3 \%)$ & 3.6 & 1.1 \\
8. & Feeling of anger & $11(18.3 \%)$ & $7(11.7 \%)$ & $42(70 \%)$ & 3.6 & 1.1 \\
9. & Low motivation & $12(20 \%)$ & $6(10 \%)$ & $42(70 \%)$ & 3.6 & 1.1 \\
10. & Low sense of efficacy & $13(21.6 \%)$ & $4(6.7 \%)$ & $43(71.3 \%)$ & 3.6 & 0.9 \\
11. & Distress & $16(26.6 \%)$ & $11(18.3 \%)$ & $33(55 \%)$ & 3.3 & 1.1 \\
12. & Absenteeism & $35(58.3 \%)$ & $6(10 \%)$ & $19(31.6 \%)$ & 2.6 & 1.3 \\
13. & Lateness to work & $29(48.3 \%)$ & $11(18.3 \%)$ & $20(33.3 \%)$ & 2.8 & 1.2 \\
14. & Interpersonal conflicts & $15(25 \%)$ & $11(18.3 \%)$ & $34(56.7 \%)$ & 3.3 & 1.1 \\
15. & Fatigue & $27(45 \%)$ & $15(25 \%)$ & $18(30 \%)$ & 2.7 & 1.2 \\
16. & Turnover intentions & $15(25 \%)$ & $6(10 \%)$ & $39(65 \%)$ & 3.4 & 1.1 \\
17. & Hostility towards pupils and colleague & $40(66.6 \%)$ & $8(5 \%)$ & $12(20 \%)$ & 2.3 & 1.4 \\
18. & teachers & $11(18.3 \%)$ & $4(6.7 \%)$ & $45(75 \%)$ & 3.8 & 1.2 \\
\hline Irritation & & & &
\end{tabular}

AVERAGE MEAN = 3.25; AVERAGE SD $=1.15$

It can be concluded from the Table 1 that factors that caused stress among teachers in special schools increased pupil enrolment $($ Mean $=3.8$; SD $=1.2$ ); lack of pupils' progress (Mean $=3.2 ; \mathrm{SD}=1.2$ ); individualized attention to students (Mean $=3.2 ; \mathrm{SD}=1.3$ ) and pupils' misbehavior (Mean $=3.2$; $\mathrm{SD}=1.2$ ). Other causes of stress among the teachers included lack of administrative support from the head teacher $($ Mean $=3.4 ; 1.4$ ); inadequate teaching and learning resources (Mean $=3.1 ; 1.2$ ); lack of parental involvement (Mean = 3.4; $\mathrm{SD}=1.3$ ); desire to change job $($ Mean $=3.2 ; \mathrm{SD}=1.2)$; low income or salary $(($ Mean = 3.7; $\mathrm{SD}=1.3$ ); limited professional training and development (Mean $=3.9 ; \mathrm{SD}=1.2$ ); and stressful professional interactions with colleagues, administrators or parents $($ Mean $=3.2 ; \mathrm{SD}=0.9)$. Increased working hours per week, lack of support staff, poor relationship with colleagues and head teachers, lack of government support, and lack of motivation were not significant sources of stress since their corresponding means were less than the average of 3 . The average means of the teachers' responses was 3.1 with 1.2 standard deviation. It can therefore be concluded that the teachers experienced some level of stress caused by the identified factors.

The Table 2 shows the teachers' responses to the effects of stress. Three major classifications of stress; i.e. physical effects (increased blood pressure, cardiovascular diseases, headaches); psychological effects (depression, anxiety, feeling of inferiority, suicidal thought, feeling of anger, low motivation, low sense of efficacy, and distress); and behavioural effects (absenteeism, lateness to work, interpersonal conflicts, fatigue, turnover intensions, hostility towards pupils and colleague teachers, and irritation). It can be seen from the Table 2 that with the physical effects, the teachers reported cardiovascular diseases (Mean $=3.1 ; \mathrm{SD}=1.2)$ and headaches $($ Mean $=$ 3.5; $\mathrm{SD}=1.2$ ) respectively. In connection with psychological effects, it can be seen that the teachers reported depression (Mean $=3.4 ; \mathrm{SD}=1.3$ ), anxiety (Mean $=3.4 ; \mathrm{SD}=1.2$ ); feeling of inferiority (Mean = 3.7; $\mathrm{SD}=$ 0.9 ); suicidal ideation (Mean $=3.6$; $\mathrm{SD}=1.1$ ); and feeling of anger $($ Mean $=3.6$; $\mathrm{SD}=1.1$ ). Other psychological effects included low motivation (Mean $=3.6$; $\mathrm{SD}=1.1$ ); low sense of efficacy (Mean $=3.6 ; \mathrm{SD}=0.9$ ); and distress $($ Mean = 3.3; SD 1.1).

Concerning the behavioural effects of stress on teachers in special schools, it can be seen that stress leads to interpersonal conflicts (Mean $=3.3$; $\mathrm{SD}=1.1$ ); turnover intentions (Mean = 3.4; SD 1.1); and irritation $($ Mean = 3.8; $\mathrm{SD}=1.2$ ). The average mean and standard deviations were 3.25 and 1.15 respectively. It can therefore be concluded that the teachers reported physical, psychological and behavioural effects of stress. 
Table 3. Coping Strategies Adopted by the Teachers

\begin{tabular}{|c|c|c|c|c|c|c|}
\hline S/no. & Coping strategies & Rarely & Sometimes & Often & Mean & Std. Dev. \\
\hline 1. & Seeking administrative support & 17 (28.3\%) & $13(21.6 \%)$ & $30(50 \%)$ & 3.2 & 1.2 \\
\hline 2. & $\begin{array}{l}\text { Access to professional training and } \\
\text { development }\end{array}$ & $21(35 \%)$ & $9(15 \%)$ & $30(50 \%)$ & 3.2 & 1.3 \\
\hline 3. & Creating mentorship & $20(33.3 \%)$ & $11(18.3 \%)$ & $29(48.3 \%)$ & 3.2 & 1.2 \\
\hline 4. & Drawing from previous success & $41(68.3 \%)$ & $10(16.7 \%)$ & $9(15 \%)$ & 2.3 & 1.0 \\
\hline 5. & Sense of efficacy & $21(35 \%)$ & $9(15 \%)$ & $30(50 \%)$ & 3.4 & 1.4 \\
\hline 6. & Positive self-talk & 39 (65\%) & $10(16.7 \%)$ & $11(18.3 \%)$ & 2.4 & 1.1 \\
\hline 7. & Leaving the stressful environment & $24(40 \%)$ & $12(20 \%)$ & $24(40.3 \%)$ & 3.1 & 1.2 \\
\hline 8. & Visiting recreation centres & 27 (45\%) & $10(16.7 \%)$ & $23(38.3 \%)$ & 2.9 & 1.3 \\
\hline 9. & Seeking social support & $18(30 \%)$ & 7 (11.7\%) & 35 (58.3\%) & 3.4 & 1.3 \\
\hline 10. & Mental imagery & $20(33.3 \%)$ & 7 (11.7\%) & $33(45 \%)$ & 3.2 & 1.2 \\
\hline 11. & Relaxation and meditation & 39 (65\%) & $9(15 \%)$ & $12(20 \%)$ & 2.4 & 1.2 \\
\hline 12. & Better nutrition & $13(21.6 \%)$ & $5(8.3 \%)$ & 42 (70\%) & 3.7 & 1.3 \\
\hline 13. & Exercise & $9(15 \%)$ & $5(8.3 \%)$ & $46(76.6 \%)$ & 3.9 & 1.2 \\
\hline 14. & Counselling services & $12(20 \%)$ & 20 (33.3\%) & 28 (46.7\%) & 3.2 & 0.9 \\
\hline
\end{tabular}

AVERAGE MEAN $=3.11 ;$ AVERAGE SD $=1.2$

Table 4. Group Statistics

\begin{tabular}{lccccc}
\hline & Sex of participants & $\mathbf{N}$ & Mean & Std. Deviation & Std. Error Mean \\
\hline \multirow{2}{*}{ Perceived sources of stress } & Male & 40 & 1.0808 & .17641 & .02789 \\
& Female & 20 & 1.1025 & .14887 & .03329 \\
\hline
\end{tabular}

Table 5. Independent t-test showing relationship between sex and perceived stress

\begin{tabular}{lcccccccc}
\hline Levene's Test for Equality of Variances & & & & & & & \\
\hline & & F & Sig. & T & df & Sig. (2-tailed) & $\begin{array}{c}\text { Mean } \\
\text { Difference }\end{array}$ \\
\hline \multirow{2}{*}{ Perceived stress } & $\begin{array}{c}\text { Equal variances assumed } \\
\text { Equal variances not assumed }\end{array}$ & & .851 & .360 & -.473 & 58 & .638 & -.02173 \\
& Equ & & & -.500 & 44.386 & .619 & -.02173 \\
\hline
\end{tabular}

Regarding coping strategies employed by the teachers to deal with stress, it can be seen that the coping strategies adopted by the teachers included seeking administrative support (Mean = 3.2; SD = 1.2); accessing professional training and development (Mean = 3.2; SD 1.3); mentorship opportunities (Mean $=3.2 ; \mathrm{SD}=1.2$ ); and sense of efficacy $($ Mean $=3.4$; SD $=1.4$ ). Other coping mechanisms reported included leaving the stressful environment $($ Mean $=3.1$; $\mathrm{SD}=1.2$ ); seeking social support $($ Mean = 3.4; $\mathrm{SD}=1.3)$; mental imagery $($ Mean = 3.2; $\mathrm{SD}=1.2$ ); better nutrition (Mean = 3.7; $\mathrm{SD}=1.3$ ); exercise (Mean $=3.9 ; 1.2$ ) and counselling services (Mean $=3.2$; $\mathrm{SD}=0.9$ ). The average mean was 3.11 while the average standard deviation was 1.2 . It can therefore be concluded that the teachers adopted various strategies to cope when they are under stress.

Further analysis was done to test the relationship between some demographic variables and the three main variables. These were done by means of independent t-test, One-Way Anova, and Pearson correlation coefficient. The relationship between sex and perceived sources of stress was estimated using independent t-test as shown in Tables 4 and 5.

Despite the significant difference in the number of male (40) and female (20) participants, it is seen that they did not differ significantly in terms of their mean scores and standard deviations $(\mathrm{X}=1.08, .17)$ and $(\mathrm{X}=1.10, .14)$ respectively. The females had slightly higher means than the males while the males however were slightly higher in terms of their standard deviations compared to the females. An independent t-test showed that, there was no significant difference in the perceived stress of males and females, $t(58)=-.47, p=.63$ as shown in Table 5 .

A test of the relationship between sex and the effects of stress (physiological, psychological, behavioural) as well as coping mechanisms is shown in Table 6 and 7. 
Table 6. Group statistics showing sex difference in means and standard deviations with respect to effects of stress and coping mechanism

\begin{tabular}{lccccc}
\hline & Sex of participants & $\mathbf{N}$ & Mean & Std. Deviation & Std. Error Mean \\
\hline \multirow{2}{*}{ Physiological effects } & Male & 40 & 1.1875 & .24657 & .03899 \\
& Female & 20 & 1.1422 & .24921 & .05573 \\
Psychological effects & Male & 40 & 1.2055 & .20823 & .03292 \\
& Female & 20 & 1.2918 & .15704 & .03512 \\
Behavioural effects & Male & 40 & 1.0748 & .26044 & .04118 \\
& Female & 20 & 1.1677 & .19351 & .04327 \\
Coping mechanism & Male & 40 & 1.1993 & .20323 & .03213 \\
& Female & 20 & 1.2569 & .11460 & .02562 \\
\hline
\end{tabular}

Table 7. Independent t-test showing relationship between sex and effects of stress and coping mechanisms

\begin{tabular}{|c|c|c|c|c|c|c|c|}
\hline \multicolumn{8}{|c|}{ Levene's Test for Equality of Variances } \\
\hline & & $\mathbf{F}$ & Sig. & $\mathbf{t}$ & Df & Sig. (2-tailed) & $\begin{array}{c}\text { Mean } \\
\text { Difference }\end{array}$ \\
\hline \multirow{2}{*}{ Physiological } & Equal variances assumed & .017 & .898 & .669 & 58 & .506 & .04532 \\
\hline & Equal variances not assumed & & & .666 & 37.746 & .509 & .04532 \\
\hline \multirow{2}{*}{ Psychological } & Equal variances assumed & 2.177 & .145 & -1.634 & 58 & .108 & -.08635 \\
\hline & Equal variances not assumed & & & -1.794 & 48.739 & .079 & -.08635 \\
\hline \multirow{2}{*}{ Behavioural } & Equal variances assumed & .220 & .641 & -1.410 & 58 & .164 & -.09289 \\
\hline & Equal variances not assumed & & & -1.555 & 49.301 & .126 & -.09289 \\
\hline \multirow{2}{*}{ Coping Mechanism } & Equal variances assumed & 1.868 & .177 & -1.175 & 58 & .245 & -.05764 \\
\hline & Equal variances not assumed & & & -1.402 & 57.032 & .166 & -.05764 \\
\hline & & Sum of Squares & Df & Mea & Square & $\mathbf{F}$ & Sig. \\
\hline \multirow{3}{*}{ Perceived stress } & Between Groups & .083 & 2 & & 042 & 1.520 & .227 \\
\hline & Within Groups & 1.558 & 57 & & 027 & & \\
\hline & Total & 1.641 & 59 & & & & \\
\hline \multirow{3}{*}{ Physiological effects } & Between Groups & .054 & 2 & & 27 & .439 & .647 \\
\hline & Within Groups & 3.524 & 57 & & 062 & & \\
\hline & Total & 3.578 & 59 & & & & \\
\hline \multirow{3}{*}{ Psychological effects } & Between Groups & .045 & 2 & & 23 & .580 & .563 \\
\hline & Within Groups & 2.214 & 57 & & 039 & & \\
\hline & Total & 2.259 & 59 & & & & \\
\hline \multirow{3}{*}{ Behavioural effects } & Between Groups & .153 & 2 & & 976 & 1.312 & .277 \\
\hline & Within Groups & 3.319 & 57 & & 058 & & \\
\hline & Total & 3.472 & 59 & & & & \\
\hline \multirow{3}{*}{ Coping mechanism } & Between Groups & .058 & 2 & & 29 & .890 & .416 \\
\hline & Within Groups & 1.847 & 57 & & 032 & & \\
\hline & Total & 1.905 & 59 & & & & \\
\hline
\end{tabular}

Both the males $(\mathrm{X}=1.18, .24)$ and females $(\mathrm{X}=$ $1.14, .24)$ did not differ significantly in terms of their means and standard deviations with respect to physiological effects of stress. This was confirmed in the results of the independent t-test of the physiological effects of stress, $t(58)=.66, p=.50$; psychological effects of stress showed a slight difference between the means and standard deviations of males $(\mathrm{X}=1.20, \mathrm{SD}=.20)$ and females $(\mathrm{X}=1.29$, SD = .15). This difference was not statistically significant as shown in the results of the independent t-test, $t(58)=-1.63, p=.10$. Also, there was a slight difference in the means and standard deviations of males $(X=1.07, \mathrm{SD}=.26)$ and females $(X=1.16, \mathrm{SD}=.19)$ in terms of behavioural effects of stress. This difference 
was not statistically significant as shown in the results of the t-test, $t(58)=-1.41, p=.16$. Again, there was a slight difference between male $(\mathrm{X}=1.19, \mathrm{SD}=.20)$ and female $(\mathrm{X}=1.25, \mathrm{SD}=.11)$ means and standard deviations with respect to coping mechanisms These did not show any statistically significant difference in the t-test, $t$ (58) $=$ $-1.17, p=.24$.

The relationship between category of school and perceived sources of stress, effects of stress and coping mechanisms was tested using One-way Analysis of Variance as shown in Table 8.

Table 8 shows that there was no significant relationship between category of school and perceived stress, effects of stress and coping mechanisms. One-way analysis of variance results showed no statistically significant difference in perceived stress among teachers based on the category of school, $F(2,57)=1.52, p=.22)$. Also, there was no significant difference among teachers based on category of school in terms of the physiological effects of stress, $F(2,57)=.43, p=.64)$; psychological effects of stress, $F(2,57)=.58, p=.56$; behavioural effects of stress, $F(2,57)=1.31, p=.22)$; and coping mechanisms $\mathrm{F}(2,57)$ $=.89, p=.41$. Thus, teachers did not differ in terms of their perceived stress, effects of stress and coping mechanisms with respect to whether they teach in school for the blind, school for the intellectually disabled or school for the deaf.

There was no significant relationship between professional qualification and perceived stress, effects of stress and coping mechanisms as shown in Table 9. One-way analysis of variance results showed no statistically significant difference in perceived stress among teachers based on professional qualification, $\mathrm{F}(2,57)$ $=.63, p=.53)$; physiological effects of stress, $\mathrm{F}(2,57)=.13$, $p=.87)$; psychological effects of stress, $\mathrm{F}(2,57)=1.92, p$ $=.15$; behavioural effects of stress, $\mathrm{F}(2,57)=.23, p=.79)$; and coping mechanisms $\mathrm{F}(2,57)=.05, p=.94$. The relationship between perceived stress and the effects of stress was tested using the Pearson correlation coefficient as presented in Tables 10, 11 and 12.

Table 9. Anova Table showing relationship between professional qualification and perceived stress, effects of stress and coping mechanisms

\begin{tabular}{|c|c|c|c|c|c|c|}
\hline & & Sum of Squares & df & Mean Square & $\mathbf{F}$ & Sig. \\
\hline \multirow{3}{*}{ Perceived stress } & Between Groups & .036 & 2 & .018 & .633 & .534 \\
\hline & Within Groups & 1.605 & 57 & .028 & & \\
\hline & Total & 1.641 & 59 & & & \\
\hline \multirow{3}{*}{ Physiological effects } & Between Groups & .017 & 2 & .008 & .134 & .875 \\
\hline & Within Groups & 3.562 & 57 & .062 & & \\
\hline & Total & 3.578 & 59 & & & \\
\hline \multirow{3}{*}{ Psychological effects } & Between Groups & .143 & 2 & .072 & 1.929 & .155 \\
\hline & Within Groups & 2.116 & 57 & .037 & & \\
\hline & Total & 2.259 & 59 & & & \\
\hline \multirow{3}{*}{ Behavioural effects } & Between Groups & .029 & 2 & .014 & .236 & .791 \\
\hline & Within Groups & 3.443 & 57 & .060 & & \\
\hline & Total & 3.472 & 59 & & & \\
\hline \multirow{3}{*}{ Coping mechanism } & Between Groups & .004 & 2 & .002 & .055 & .947 \\
\hline & Within Groups & 1.901 & 57 & .033 & & \\
\hline & Total & 1.905 & 59 & & & \\
\hline
\end{tabular}

Table 10. Correlations Table showing relationship between perceived stress and physiological effects of stress

\begin{tabular}{llcc}
\hline & & Perceived stress & Physiological effects \\
\hline \multirow{3}{*}{ Perceived stress } & Pearson Correlation & 1 & $.259^{*}$ \\
& Sig. (2-tailed) & & .045 \\
& $\mathrm{~N}$ & 60 & 60 \\
Physiological effects & Pearson Correlation & $.259^{*}$ & 1 \\
& Sig. (2-tailed) & .045 & 60 \\
\hline
\end{tabular}

*. Correlation is significant at the 0.05 level (2-tailed). 
There was a significant relationship between perceived stress and physiological effects of stress $r(58)=.25, p=.04$ as shown in Table 10. Table 11 shows the results between perceived stress and psychological effects of stress.

Table 11. Correlation between perceived stress and psychological effects of stress

\begin{tabular}{llcc}
\hline & & $\begin{array}{c}\text { Perceived } \\
\text { stress }\end{array}$ & $\begin{array}{c}\text { Psychological } \\
\text { effects }\end{array}$ \\
\hline Perceived & Pearson Correlation & 1 & .052 \\
stress & Sig. (2-tailed) & & .694 \\
& $\mathrm{~N}$ & 60 & 60 \\
Psychological & Pearson Correlation & .052 & 1 \\
effects & Sig. (2-tailed) & .694 & \\
& $\mathrm{~N}$ & 60 & 60 \\
\hline
\end{tabular}

Table 11 shows no significant relationship between perceived stress and psychological effects of stress $r(58)$ $=.05, p=.69$ as evidenced in Pearson's correlation coefficient. Table 12 shows the relationship between perceived stress and behavioural effects of stress.

Table 12. Correlations Table showing relationship between perceived stress and behavioural effects of stress

\begin{tabular}{llcc}
\hline & & $\begin{array}{c}\text { Perceived } \\
\text { stress }\end{array}$ & $\begin{array}{c}\text { Behavioural } \\
\text { effects }\end{array}$ \\
\hline $\begin{array}{l}\text { Perceived } \\
\text { stress }\end{array}$ & Pearson Correlation & 1 & .075 \\
& Sig. (2-tailed) & & .569 \\
& $\mathrm{~N}$ & 60 & 60 \\
$\begin{array}{l}\text { Behavioural } \\
\text { effects }\end{array}$ & Pearson Correlation & .075 & 1 \\
& Sig. (2-tailed) & .569 & \\
\hline
\end{tabular}

The Pearson moment correlation coefficient in Table 12 shows no significant relationship between perceived stress and behavioural effects of stress $r(58)=.07, p=.56$. Table 13 shows the relationship between perceived stress and coping mechanisms.

Table 13. Correlation between perceived stress and coping mechanisms

\begin{tabular}{llcc}
\hline & & $\begin{array}{c}\text { Perceived } \\
\text { stress }\end{array}$ & $\begin{array}{c}\text { Coping } \\
\text { mechanism }\end{array}$ \\
\hline Perceived & Pearson Correlation & 1 & .119 \\
stress & Sig. (2-tailed) & & .366 \\
& $\mathrm{~N}$ & 60 & 60 \\
Coping & Pearson Correlation & .119 & 1 \\
mechanism & Sig. (2-tailed) & .366 & \\
& $\mathrm{~N}$ & 60 & 60 \\
\hline
\end{tabular}

Table 13 shows the correlation between perceived stress and coping mechanisms which was not statistically significant, $r(58)=.11, p=.36$. Tables 14,15 and 16 respectively show the relationship between physiological, psychological, and behavioural effects of stress and coping mechanism.

Table 14. Correlation between physiological effects of stress and coping mechanisms

\begin{tabular}{llcc}
\hline & & $\begin{array}{c}\text { Coping } \\
\text { mechanism }\end{array}$ & $\begin{array}{c}\text { Physiological } \\
\text { effects }\end{array}$ \\
\hline Coping & Pearson Correlation & 1 & .067 \\
mechanism & Sig. (2-tailed) & & .612 \\
& $\mathrm{~N}$ & 60 & 60 \\
& Pearson Correlation & .067 & 1 \\
Physiological \\
effects
\end{tabular}

It is evident in Table 14 that there was no significant relationship between physiological effects of stress and coping mechanisms, $r(58)=.06, p=.61$.

Table 15. Correlations between psychological effects of stress and coping mechanisms

\begin{tabular}{llcc}
\hline & & $\begin{array}{c}\text { Coping } \\
\text { mechanism }\end{array}$ & $\begin{array}{c}\text { Psychological } \\
\text { effects }\end{array}$ \\
\hline Coping & Pearson Correlation & 1 & .007 \\
mechanism & Sig. (2-tailed) & & .957 \\
& $\mathrm{~N}$ & 60 & 60 \\
& Pearson Correlation & .007 & 1 \\
Psychological & Sig. (2-tailed) & .957 & \\
& $\mathrm{~N}$ & 60 & 60 \\
\hline
\end{tabular}

It can be seen in Table 15 that there was no significant relationship between psychological effects of stress and coping mechanisms, $r(58)=.007, p=.95$.

Table 16. Correlation between behavioural effects of stress and coping mechanisms

\begin{tabular}{llcc}
\hline & Pearson Correlation & $\begin{array}{c}\text { Coping } \\
\text { mechanism }\end{array}$ & $\begin{array}{c}\text { Behavioural } \\
\text { effects }\end{array}$ \\
\hline $\begin{array}{l}\text { Coping } \\
\text { mechanism }\end{array}$ & Sig. (2-tailed) & 1 & $.457^{* *}$ \\
& $\mathrm{~N}$ & 60 & .000 \\
& Pearson Correlation & $.457^{* *}$ & 60 \\
$\begin{array}{l}\text { Behavioural } \\
\text { effects }\end{array}$ & Sig. (2-tailed) & .000 & 1 \\
& $\mathrm{~N}$ & 60 & 60 \\
\hline
\end{tabular}

**. Correlation is significant at the 0.01 level (2-tailed).

Table 16 shows a significant relationship between behavioural effects of stress and coping mechanisms, $r(58)$ $=.457, p=.00$. 
Table 17. Anova of professional qualification and effects of stress

\begin{tabular}{|c|c|c|c|c|c|c|}
\hline & & Sum of Squares & df & Mean Square & $\mathbf{F}$ & Sig. \\
\hline \multirow{3}{*}{ Physical effects } & Between Groups & .017 & 2 & .008 & .134 & .875 \\
\hline & Within Groups & 3.562 & 57 & .062 & & \\
\hline & Total & 3.578 & 59 & & & \\
\hline \multirow{3}{*}{ Psychological effects } & Between Groups & .143 & 2 & .072 & 1.929 & .155 \\
\hline & Within Groups & 2.116 & 57 & .037 & & \\
\hline & Total & 2.259 & 59 & & & \\
\hline \multirow{3}{*}{ Behavioural effects } & Between Groups & .029 & 2 & .014 & .236 & .791 \\
\hline & Within Groups & 3.443 & 57 & .060 & & \\
\hline & Total & 3.472 & 59 & & & \\
\hline
\end{tabular}

Table 18. Anova of Professional qualification and coping mechanisms

\begin{tabular}{lccccc}
\hline & Sum of Squares & Df & Mean Square & F & Sig. \\
\hline Between Groups & .004 & 2 & .002 & .055 & .947 \\
Within Groups & 1.901 & 57 & .033 & & \\
Total & 1.905 & 59 & & & \\
\hline
\end{tabular}

Table 19. Relationship between Teaching hours per week and stress, effects of stress and coping mechanisms

\begin{tabular}{|c|c|c|c|c|c|c|}
\hline & & Sum of Squares & df & Mean Square & $\mathbf{F}$ & Sig. \\
\hline & Between Groups & .150 & 4 & .037 & 1.383 & .252 \\
\hline \multirow[t]{3}{*}{ Perceived stress } & Within Groups & 1.491 & 55 & .027 & & \\
\hline & Total & 1.641 & 59 & & & \\
\hline & Between Groups & .025 & 4 & .006 & .095 & .984 \\
\hline \multirow[t]{3}{*}{ Physical effects } & Within Groups & 3.554 & 55 & .065 & & \\
\hline & Total & 3.578 & 59 & & & \\
\hline & Between Groups & .102 & 4 & .026 & .652 & .628 \\
\hline \multirow[t]{3}{*}{ Psychological effects } & Within Groups & 2.157 & 55 & .039 & & \\
\hline & Total & 2.259 & 59 & & & \\
\hline & Between Groups & .097 & 4 & .024 & .396 & .811 \\
\hline \multirow[t]{3}{*}{ Behavioural effects } & Within Groups & 3.375 & 55 & .061 & & \\
\hline & Total & 3.472 & 59 & & & \\
\hline & Between Groups & .008 & 4 & .002 & .058 & .994 \\
\hline \multirow[t]{2}{*}{ Coping mechanism } & Within Groups & 1.897 & 55 & .034 & & \\
\hline & Total & 1.905 & 59 & & & \\
\hline
\end{tabular}

Table 17 shows the relationship between professional qualification and the effects of stress estimated by one-way analysis of variance. It is seen that there was no significant relationship between professional qualification and the effects of stress - physiological effects, $F(2,57)=.13, p$ $=.87$; psychological effects $F(2,57)=1.92, p=.15$; and behavioural effects, $F(2,57)=.23, p=.79$.

The Anova results in table 18 shows no significant relationship between professional qualification and coping mechanism, $F(2,57)=.05, p=.84$.
Table 19 depicts the results of one-way analysis of variance showing the relationship between teaching hours per week and perceived stress, effects of stress and coping mechanism. It is seen that there was no significant relationship between preparation hours per week and perceived stress $F(4,55)=1.38, p=.25$; physical effects of stress, $F(4,55)=.09, p=.98$; psychological effects of stress, $F(4,55)=.65, p=.62$; behavioural effects, $F(4,55)=.39, p$ $=.811$; and coping mechanisms, $F(4,55)=.05 ; p=.99$. 
Table 20. Relationship between Preparation hours per week and perceived stress, effects of stress and coping mechanisms

\begin{tabular}{|c|c|c|c|c|c|c|}
\hline & & Sum of Squares & df & Mean Square & $\mathbf{F}$ & Sig. \\
\hline & Between Groups & .039 & 4 & .010 & .334 & .854 \\
\hline \multirow[t]{3}{*}{ Perceived stress } & Within Groups & 1.602 & 55 & .029 & & \\
\hline & Total & 1.641 & 59 & & & \\
\hline & Between Groups & .285 & 4 & .071 & 1.190 & .325 \\
\hline \multirow[t]{3}{*}{ Physiological effects } & Within Groups & 3.293 & 55 & .060 & & \\
\hline & Total & 3.578 & 59 & & & \\
\hline & Between Groups & .431 & 4 & .108 & 3.244 & .018 \\
\hline \multirow[t]{3}{*}{ Psychological effects } & Within Groups & 1.828 & 55 & .033 & & \\
\hline & Total & 2.259 & 59 & & & \\
\hline & Between Groups & .090 & 4 & .022 & .365 & .832 \\
\hline \multirow[t]{3}{*}{ Behavioural effects } & Within Groups & 3.382 & 55 & .061 & & \\
\hline & Total & 3.472 & 59 & & & \\
\hline & Between Groups & .086 & 4 & .022 & .653 & .628 \\
\hline \multirow[t]{2}{*}{ Coping mechanism } & Within Groups & 1.818 & 55 & .033 & & \\
\hline & Total & 1.905 & 59 & & & \\
\hline
\end{tabular}

The results of one-way analysis of variance in Table 20 shows no significant relationship between preparation hours per week and perceived stress, $F(4,55)=.33, p=.85$ ), physiological effects of stress, $F(4,55)=1.19, p=.32$ ), behavioural effects of stress, $F(4,55)=.36, p=.83$ ), and coping mechanisms, $F(4,55)=.65, p=.62)$. Only the psychological effects of stress showed significant relationship with preparation hours per week, $F(4,55)=$ $3.24, p=.01)$.

\section{Discussion}

The data obtained from the teachers' responses to the questionnaire items showed that various factors influenced stress among teachers in special schools. Such factors included increased pupil enrolment, lack of pupils' progress, need for special attention to pupils, pupils' challenging behaviours, lack of administrative support, inadequate teaching and learning resources, lack of parental involvement, desire to change job, low remuneration, limited professional training and stressful professional interactions. These sources of stress corroborate other earlier findings [51] who reported inadequate resources and students challenging behaviours [29] as a source of stress. Other earlier literature has also been confirmed in this study, including limited or stressful professional interactions [48], [58], limited professional training and development [4], and lack of students' progress [1]. However, lack of instructional support and lack of support staff were not considered stressful contrary to what had been reported in literature [1], [51]

Concerning the effects of stress on special education teachers, it was revealed that the teachers experienced physical, psychological, and behavioural effects of stress.
The physical effects reported included cardiovascular diseases and headaches. The psychological effects of stress included depression, anxiety, feeling of inferiority, suicidal thoughts, anger, low motivation, low self-efficacy and distress. Finally, the behavioural effects of stress included interpersonal conflicts, turnover intentions, and irritation. These findings are consistent with other earlier studies that have reported physical, psychological and behavioural effects of stress [18]. Feeling of inferiority and turnover intensions reported in this study also confirm other earlier studies [51]. Cardiovascular disease, anxiety, and feelings of inadequacy also corroborate the findings of Punch [52]. Depression as also reported by Betoret [12] which was supported in this study.

Again, the data revealed that seeking administrative support, access to professional training and development, creating mentorship programmes, sense of efficacy, leaving the stressful environment, seeking social support mental imagery, proper nutrition, physical exercise, and counselling services are some of the strategies used in coping with stress. These support earlier literature such as seeking social support and seeking administrative support [33], [62]. Also, access to professional training and development confirms the findings of Winiski [61]. Availability of mentorship programmes, the use of positive self-talk, drawing from previous success and sense of self-efficacy confirms earlier research [7], [34]. Other strategies found in this study include counselling services, mental imagery, and separation from stressful events.

Finally, it was revealed from the data that there was no significant difference between males and females in terms of their perceived stress, effects of stress, and coping mechanisms. Thus, among special education teachers, one's sex does not determine their perceived stress, effects of stress, and the mechanisms they adopt to cope with their 
stress. This was also so with professional qualification since no significant relationship was found between professional qualification and perceived stress, effects of stress and coping mechanisms. There was a significant relationship between perceived stress and physiological effects of stress. Thus, perceived stress among special educators had significant physiological effects than psychological and behavioural effects which showed no significant relationship with perceived stress. Also, there was no significant relationship between perceived stress and coping mechanism. Thus, special educators' perceived stress did not affect the strategies they adopted to cope with stress. There was no relationship between professional qualification and the effects of stress as well as coping mechanisms. Further, there was no relationship between teaching hours and perceived stress, effects of stress, and coping mechanisms. Thus, the number of hours one teaches in a week has no influence on perceived stress, effects of stress and coping strategies among special educators. Concerning preparation hours, it was found that there was no significant relationship between perceived stress, physiological effects of stress, behavioural effects of stress and coping mechanisms. However, there was a significant relationship between preparation hours and psychological effects of stress. This may be so because of the amount of time teachers may spend in preparing to teach special needs students which may lead to mental strain, hence significant psychological effect.

\section{Conclusions}

Studies on stress among special education teachers remain underrepresented in research literature. It must however be emphasized from the findings of the study that several factors cause stress among special education teachers. These factors have a significant impact on physical health, psychological well-being as well as social and behavioural dimensions of special education teachers. There is therefore the need for all stakeholders in education to join hands in dealing with this issue of stress among special education teachers so that they can put off their best in helping to educate and train special needs of children who remain in special schools in this era of inclusive education. Efforts should be made to reduce the physiological effects of stress since this has influence on coping mechanisms. Also, constant social support and counselling services should be provided for teachers in their preparation hours so that they do not become psychologically strained to affect their preparation and performance in class.

\section{Recommendations}

First, the government must ensure effective compensation policies to ensure that special education teachers are motivated enough and feel less stress in their job. The more an individual has resources to meet demands, the less stress he or she becomes. Secondly, government agencies, non-governmental organizations, parents and school administrators must provide adequate teaching and learning materials to help the teachers in the effective delivery of their lessons. School administrators must ensure administrative support and foster good interpersonal relationships among the staff of the school to reduce teacher stress that comes from poor relationships with administrators and colleague teachers. It is recommended that special schools should have effective social support systems with trained counselling professionals to provide the necessary interventions to teachers during their stress moments. Again, special schools should also have recreational centres where teachers can relax when they are stressed from their work.

\section{REFERENCES}

[1] Adeniyi, S. O., Fakolade, O. A. \& Tella, A., "Perceived causes of job stress among special educators in selected special and integrated schools in Nigeria,” New Horizons in Education, vol. 58, no. 2, pp. 73-82, 2010.

[2] Albrecht, Susan Fread, Beverley H. Johns, Joyce Mounsteven, and Olufunmilola Olorunda. "Working conditions as risk or resiliency factors for teachers of students with emotional and behavioral disabilities," Psychology in the Schools, vol. 46, no. 10, pp. 1006-1022, 2009.

[3] Anderson, Lauren, and Brad Olsen, "Investigating early career urban teachers' perspectives on and experiences in professional development," Journal of teacher education, vol. 57, no. 4, pp. 359-377, 2006.

[4] Anderson, L.W. \& Pellicer, L. O., “Teacher peer assistance and review,” Thousand Oaks: Corwin, 2001.

[5] Antonovsky, A. "Unravelling the mystery of health: how people manage stress and stay well," San Francisco, CA: Jossey-Bass, 1987.

[6] Antoniou, A.S., Polychroni, F. \& Walters, B. "Sources of stress and professional burnout of teachers of special educational needs in Greece (ISEC)," Paper presented at International Special Education Congress, Including the Excluded, University of Manchester, 2000.

[7] Bandura, A. "Perceived self-efficacy in cognitive development and functioning," Educational Psychologist, vol. 28, pp. 117-148, 1993.

[8] Beck, C. L. \& Garguilo, R. M., "Burnout in teachers of retarded and nonretarded children," Journal of Educational Research, vol. 76, no. 3, pp. 169-173, 2001.

[9] Beltman, Susan, Caroline Mansfield, and Anne Price. "Thriving not just surviving: A review of research on teacher resilience." Educational research review, vol. 6, no. 3, pp. 185-207, 2011.

[10] Bester, G. \& Swanepoel, L. "Stress in the learning situation: 
A multivariable and developmental approach," South African Journal of Education, vol. 20, pp. 255-259, 2000.

[11] Bettini, Elizabeth, Nathan Jones, Mary Brownell, Maureen Conroy, Yujeong Park, Walter Leite, Jean Crockett, and Amber Benedict, "Workload manageability among novice special and general educators: Relationships with emotional exhaustion and career intentions," Remedial and Special Education, vol. 38, no. 4, pp. 246-256, 2017.

[12] Betoret, F. D., "Stressors, self-efficacy, coping resources, and burnout among secondary teachers in Spain," Educational Psychology, vol. 26, pp. 519-539, 2006.

[13] Billingsley, Bonnie S., "Teacher retention and attrition-in special and general education: A critical review of the literature," The Journal of Special Education, vol. 27, no. 2, pp. 137-174, 1993.

[14] Billingsley, B. S., "Special education teacher retention and attrition: A critical analysis of the research literature,” The Journal of Special Education, vol. 38, no. 1, pp. 39-55, 2004.

[15] Bishop, G. D., "Health psychology: integrating mind and body.” Massachusetts: Allyn \& Bacon, 1994.

[16] Brannon, L. \& Feist, J., "Health psychology: an introduction to behaviour and health,” Belmont, CA: Wadsworth, 2000.

[17] Brown, O., “The biopsychosocial coping and adjustment of medical professional women,” Unpublished master's thesis, University of Port Elizabeth, Port Elizabeth, 2002.

[18] Brown, O., Howcroft, G., \& Jacobs, T. S., "The coping orientation and resources of teachers educating learners with intellectual disabilities," South African Journal of Psychology, vol. 39, pp. 448, 2009.

[19] Brownell, M., \& Smith, S., “Understanding special education teacher attrition: A conceptual model and implications for teacher educators," Teacher Education and Special Education, vol. 16, pp. 370-382, 1993.

[20] Burke, R. J., \& Greenglass, E. R., "Work stress, role conflict, social support, and psychological burnout among teachers," Psychological Reports, vol. 73, pp. 371-380, 1995.

[21] Burns, N. \& Grove, S. K., "The practice of nursing research conduct, critique and utilization,” Philadelphia: Sounder Co, 1983.

[22] Burns, R., “Coping with stress,” Cape Town: Maskew Miller Longman, 1988.

[23] Cancio, Edward J., Ross Larsen, Sarup R. Mathur, Mary Bailey Estes, Bev Johns, and Mei Chang, "Special education teacher stress: Coping strategies," Education and Treatment of Children, vol. 41, no. 4, pp. 457-481, 2018.

[24] Cancio, Edward J., and Greg Conderman, "Promoting longevity: Strategies for teachers of students with emotional and behavioral disorders." Beyond Behavior, vol. 17, no. 3, pp. 30-36, 2008.

[25] Castro, Antonio J., John Kelly, and Minyi Shih. "Resilience strategies for new teachers in high-needs areas," Teaching and Teacher Education, vol. 26, no. 3, pp. 622-629, 2010.

[26] Chan, D. W., "Stress, coping strategies and psychological distress among secondary school teachers in Hong Kong," American Educational Research Journal, vol. 35, pp. 145163, 1998.
[27] Chaplain, R. P., "Stress and psychological distress among trainee secondary teachers in England," Educational Psychology, vol. 28, no. 2, pp. 195-209, 2008.

[28] Clipa, Otilia, "Teacher stress and coping strategies." In Studies and Current trends in Science of Education, pp. 120-128. Editura Lumen, Asociatia Lumen, 2017.

[29] Cox, T., “Stress,” London: Macmillan, 1978.

[30] Croll, Paul, and Diana Moses. "Ideologies and utopias: Education professionals' views of inclusion." European journal of special needs education, vol. 15, no. 1, pp. 1-12, 2000

[31] Crider, A. B., Goethals, G. R., Kavanaugh, R. D., \& Solomon, P. R., "Psychology. (4thed.)," New York: HarperCollins College Publishers, 1993.

[32] Croll, P., \& Moses, D., "Special needs in the primary school," London: Cassell, 2000.

[33] Cross, L. H., \& Billingsley, B., “Testing a model of special educators' intent to stay in teaching,” Exceptional Children, vol. 60, pp. 411-421, 1994.

[34] Dunham, J., "Stress in teaching,” New York: Routledge Publishing, 1996.

[35] Ellen, P., \& Susann, D., “What is psychology,” New York: Homson Wadsworth, 2006.

[36] Eloff, I., Engelbrecht, P., Oswald, M., \& Swart, E., "Including learners with intellectual disabilities: stressful for teachers?” International Journal of Disability, Development and Education, vol. 50, no. 3, pp. 293-308, 2003.

[37] Futernick, Ken, "A possible dream: Retaining California teachers so all students learn," Sacramento: California State University, 2007.

[38] Gersten, R., Keating, T., Yovanoff, P., \& Harniss, M. K., Working in special education: Factors that enhance special educators' intent to stay. Exceptional Children, vol. 67, no. 4, pp. 549-567, 2001.

[39] Ghania, M. Z, Ahmadb, A. C., \& Ibrahimc, S., "Stress among special education teachers in Malaysia," Procedia Social and Behavioural Sciences, vol. 114, pp. 4 -13, 2014.

[40] Gyimah, K. A., \& Duodu, F., "Introduction to research methods in education,” Winneba: IEDE - UEW, 2006.

[41] Jones, Nathan D., Peter Youngs, and Kenneth A. Frank, "The role of school-based colleagues in shaping the commitment of novice special and general education teachers," Exceptional children, vol. 79, no. 3, pp. 365-383, 2013.

[42] Katsiyannis, Antonis, Dalun Zhang, and Maureen A. Conroy, "Availability of special education teachers: Trends and issues," Remedial and special education, vol. 24, no. 4 pp. 246-253, 2003.

[43] Kaur, S., "Comparative study of occupational stress among teachers of private and government schools in relation to their age, gender and teaching experience,” International Journal of Educational Planning \& Administration, vol. 2, pp. 151-160, 2011.

[44] Lazarus, Richard S. "From psychological stress to the emotions: A history of changing outlooks." Annual review 
of psychology, vol. 44, no. 1, 1-22, 1993.

[45] Lazarus, R. S., \& Folkman, S., "Stress, appraisal and coping," New York: Springer, 1984.

[46] Miller, M. D., Brownell, M., \& Smith, S. W., "Factors that predict teachers staying in, leaving, or transferring from the special education classroom,” Exceptional Children, vol. 65, no. 2, pp. 208-218, 1999.

[47] Ogden, J., "Health psychology: A textbook. (3rd ed.)," Berkshire, England: Open University Press, 2004.

[48] Otto, S. J., \& Arnold, M., "A study of experienced special education teachers' perceptions of administrative support," College Student Journal, vol. 39, no. 2, pp. 253-257, 2005.

[49] Parker, Philip D., and Andrew J. Martin, "Coping and buoyancy in the workplace: Understanding their effects on teachers' work-related well-being and engagement," Teaching and Teacher Education, vol. 25, no. 1, 68-75, 2009.

[50] Pepe, A., \& Addimando, L., "Comparison of occupational stress in response to challenging behaviours between general and special education primary teachers in northern," International Journal of Special Education, 28, 2013.

[51] Prather-Jones, Bianca, Rachelle M. Bruno, and Stephen C. Walker. "Are Teaching Effectiveness and Retention Influenced by Various Routes to Special Education Certification?." Kentucky Teacher Education Journal: The Journal of the Teacher Education Division of the Kentucky Council for Exceptional Children, vol. 1, no. 1, pp. 3, 2011.

[52] Punch, K. F. \& Tuettemann, E., “Correlates of psychological distress among secondary school teachers," British Educational Journal, vol. 16, pp. 369-382, 1990.
[53] Sanderson, C. A., “Health psychology,” Hoboken, N. J.: John Wiley, 2004.

[54] Sarafino, E. P., "Health psychology: biopsychosocial interactions,” (4th ed.). New York, NY: Wiley, 2008.

[55] Saunders, Mark, Philip Lewis, and Adrian Thornhill. "Research methods for business students (6. utg.)." Harlow: Pearson (2012).

[56] Schlichte, Jacqueline, Nina Yssel, and John Merbler. "Pathways to burnout: Case studies in teacher isolation and alienation," preventing school failure: Alternative Education for Children and Youth, vol. 50, no. 1, pp. 35-40, 2005.

[57] Schutz, P. A. \& Zembylas, M., "Introduction to advances in teacher emotion research: the impact on teachers' lives," 2009. In P. A. Schutz \& M. Zambylas (Eds.), Advance in teacher emotion research (pp 3-11). New York: Springer.

[58] Stempien, L. R., \& Loeb, R. C., "Differences in job satisfaction between general education and special education teachers," Remedial and Special Education, vol. 23, no. 5, pp. 258-267, 2002.

[59] Travers, C. J., \& Cooper, C. L., "Teachers under pressure: Stress in the teaching professor,” London: Routledge, 1996.

[60] Williams, E. E., "Teaching the mentally handicapped child: challenges faced by teachers,” Unpublished master's treatise, University of Port Elizabeth, Port Elizabeth, 2003.

[61] Wisniewski, L., \& Garguilo, R. M., "Occupational stress and burnout among special educators: A review of the literature," Journal of Special Education, vol. 31, no. 3, pp. 325-347, 1997.

[62] Yee, S., "Career in the classroom: When teaching is more than a job,” New York: Teachers College Press, 1990. 